\title{
Penggunaan Metode Pembelajaran Peta Konsep untuk Meningkatkan Hasil Belajar IPS Dan Karakter Nasionalis Siswa Kelas IV SD Inpres Semangga 1 Merauke
}

\author{
K W Lieung ${ }^{a}$, D P Rahayu ${ }^{b}$ \\ Program Studi Pendidikan Guru Sekolah Dasar \\ Fakultas Keguruan dan Ilmu Pendidikan - Universitas Musamus \\ Corresponding e-mail: lieung@unmus.ac.id
}

\begin{abstract}
Abstrak: Permasalahan yang terjadi pada siswa kelas IV SD Inpres Semangga 1 Kabupaten Merauke yaitu pentingnya meningkatkan hasil belajar IPS dan karakter nasionalis siswa. Penelitian ini bertujuan untuk meningkatkan hasil belajar IPS pada tema indahnya keragaman di negeriku dan karakter nasionalis siswa kelas IV SD Inpres Semangga 1 Kabupaten Merauke. Penelitian ini merupakan penelitian tindakan kelas. Penelitian dilaksanakan dalam tiga siklus dengan tiap siklus terdiri dari perencanaan, tindakan, observasi, dan refleksi. Subjek penelitian ini adalah siswa kelas IV SD Inpres Semangga 1 Kabupaten Merauke. Data yang digunakan dalam penelitian ini adalah siswa, guru, dan observer. Analisis data menggunakan teknik kuantitatif dan kualitatif, meliputi reduksi data, penyajian data, dan penarikan simpulan. Hasil pretes siswa kelas IV menggunakan metode peta konsep sebesar 41. 76, siklus I sebesar 72. 06, siklus II 76. 47, dan siklus III 80. 59. Karakter nasionalis siswa dari siklus I berkategori sudah membudaya sebesar $17.65 \%$, siklus kedua sebesar 70. $59 \%$ dan pada siklus III sebesar $94.12 \%$.
\end{abstract}

Kata Kunci: Metode Pembelajaran Peta Konsep, Hasil Belajar, Karakter Nasionalis.

Abstract: The problem that occurs in fourth grade students of SD Inpres Semangga 1, Merauke Regency is the importance of improving social studies and the nationalist character of students. This study aims to improve social studies learning outcomes on the beauty of diversity in my country theme and the nationalist character of fourth grade SD Inpres Semangga 1, Merauke Regencies students. This research is a classroom action research. The study was conducted in three cycles with each cycle consisting of planning, action, observation, and reflection. The studies subjects were the fourth grade students of SD Inpres Semangga 1, Merauke Regency. The data used in this study were students, teachers, and observers. Data analysis uses quantitative and qualitative techniques, including data reduction, data presentation, and drawing conclusions. The results of pretest grade IV students used the concept map method of 41.76, increasing in the first cycle of 72. 06, second cycle 76. 47, and third cycle 80. 59. The nationalist character of the students from the first cycle was categorized by $17.65 \%$, increased in the second cycle by $70.59 \%$ and in the third cycle was 94. $12 \%$.

Keywords: mind mapping method,learning outcomes, national character 


\section{PENDAHULUAN}

Pembelajaran yakni proses pendidikan yang dipengaruhi berbagai aspek. Aspek-aspek tersebut diantaranya pengajar, pebelajar, metode, model strategi, serta media pembelajaran. Kegiatan pembelajaran dapat sukses apabila memakai model, metode maupun teknik yang bisa memudahkan pemahaman materi.

Tema pembelajaran pada kelas empat SD diantaranya yakni indahnya keragaman di negeriku. Tema ini mempelajari keberagaman Indonesia. Bayaknya agama, etnis serta budaya yang dimiliki Indonesia cukup memberatkan siswa dalam memahami materi-materi tersebut.

Salah satu metode yang tepat untuk membantu siswa menguasai materi indahnya keragaman di negeriku adalah metode pembelajaran peta konsep. Metode pembelajaran ini menuntut siswa membuat peta konsep. Penggunaan peta konsep tersebut diharapkan membantu siswa menguasai materi.

Dengan mempelajari indahnya keragaman di negeriku diharapkan siswa dapat lebih merasa bangga dengan keragaman Indonesia serta turut melestarikan budaya Indonesia sehingga memicu meningkatnya karakter nasionalis pada diri siswa.

Penelitian ini penting untuk dilaksanakan mengingat banyaknya keberagaman yang ada di Indonesia yang harus dikuasai siswa, sehingga memlalui metode pembelajaran peta konsep diharapkan mampu menolong siswa menguasai topik tersebut.

Terlebih untuk siswa kelas IV SD Inpres Semangga 1 Kabupaten Merauke yang notabene berada di ujung timur Indonesia hendaknya memiliki rasa bangga akan keberagaman di Indonesia sehingga karakter nasionalis meningkat.

Penelitian ini memiliki rumusan masalah yakni: 1. Bagaimana penggunaan metode pmebelajaran peta konsep untuk meningkatkan hasil belajar IPS pada tema indahnya keragaman di negeriku siswa kelas IV SD Inpres Semangga 1 Kabupaten Merauke?, 2. Bagaimana penggunaan metode pembelajaran peta konsep untuk meningkatkan karakter nasionalis siswa kelas IV SD Inpres Semangga 1 Kabupaten Merauke?

Tujuan penelitian ini adalah meningkatkan hasil belajar IPS dan karakter nasionalis siswa kelas empat SD Inpres Semngga 1 Kabupaten Merauke.

Metode pembelajaran peta konsep ini berkaitan dengan keinginan siswa untuk belajar berdiskusi, senang bertanya dan menjawab pertanyaan, dan juga senang menyelesaikan semua tugasnya. Cara yang bisa ditempuh agar pembelajaran siswa bermakna yakni memakai metode peta konsep.

Peta konsep yakni salah satu konsep yang menghadirkan hubungan-hubungan yang berarti. Konsep tersebut dihubungkan dengan memakai kata khusus sehingga memunculkan keterhubungan (Fahzurrohman, 2015:205).

Otak manusia menabung info dengan desain dan gabungan layaknya tumbuhan dengan cabang-cabangnya. Peta konsep memakai pengingat gambar dan sensor pada sesuatu desain pada gagasan-gagasan yang berhubungan, seperti denah jalan yang dipakai guna belajar mengorganisasikan dan merencanakan.

Peta konsepyaknisesuatu gaya yang dinamis gunamendapatkan item-item pokok informasi yang spesifik. Dengan demikian, Peta konsep berarti penyamarataan yang menolong mengelompokkan dan mengatur pengetahuan dan pengalaman serta guna memprediksikan (Yusron, 2013:39).

Peta konsep menunjukkan hirarki dari kaidahkaidah. Kaidah-kaidah tersebut itu tidak mempunyai besaran yang sama. Kaidah yang cenderung umum diposisikan di atas, dan kaidah yang tidak cukup umum diposisikan di bagian paling atas. Pemetaan konsep dalam pembelajaran diterapkan dengan meminta siswa membuat kaitan diantara konsep-konsep. Teknik penggunaannya bisa dengan menata konsep-konsep yang telah disiapkan oleh guru di atas sehelai kertas dan kemudiannya konsepkonsep ini dihubungkan dengan proposi yang membentuk kalimat yang bermakna (Junaedi dkk, 2008:11).

Peta konsep menjadi alternatif teknik pembelajaran kolaboratif, dalam arti peta konsep dibuat sebagai hasil kerja dari kelompok siswa. Aktivitas membuat representasi visual dari konsep-konsep semacam ini memiliki keuntungan bahwa simbol-simbol visual lebih cepat dan lebih mudah dikenal. Representasi visual semacam ini memberikan kesempatan untuk pengembangan pemahaman siswa terhadap suatu materi (Warsono dan Hariyanto, 2012:124).

Tujuan dari metode peta konsep dalam pembelajaran menurut Dahar (2011:110) yaitu:

a. Menyelidiki pengetahuan peserta didik

b. Kegiatan belajar menjadi berarti jika memakai daya yang kuat dari siswa untuk mengasosiasikan pengetahuan dengan konsep yang telah yang berhubungan yang sudah peserta didik miliki.

c. Mengkaji sistem belajar 
d. Belajar menjadi berarti jika penciptaan peta konsep muncul dari kemauan peserta didik guna menguasai materi pelajaran.

e. Menunjukkan relasi gagasan-gagasan siswa dan menolong menguasai yang sudah dipelajari

f. Membuat peserta didik memiliki keterampilan menggali pengetahuan mula yang dipunyai serta mendapatkan pengetahuan yang selaras dengan pengalaman belajar peserta didik.

Menurut Junaedi (2008) , kelebihan Peta konsep yakni:

a. Menolong peserta didik mengkonstruksi pengetahuannya secara mandiri.

b. Menolong peserta didik untuk mengintegrasikan pengetahuan baru dan lama.

c. Mampu dipakai sebagai pengganti rangkuman yang praktis serta fleksibel

d. Mampu memudahkan pemahaman guru dan peserta didik. Serta menyamakan pendapat.

e. Kreativitas peserta didik mampu ditingkatkan guna menentukan konsep.

f. Sebagai sistem evaluasi dalam pembelajaran. Kelemahan metode peta konsep yakni:

a. Peserta didik yang belum lancar membaca akan mengalami kesulitan.

b. Waktu yang diperlukan cukup lama.

c. Pembelajaran menjadi kurang tenang karna setiap siswa memiliki keinginan menyampaikan ide.

Terjadinya perubahan dalam diri individu pasca proses belajar dinamakan hasil belajar. Bloom dalam Rusman dkk (2011: 12) berpendapat bahwa "perubahan perilaku hasil belajar mencakup adanya perubahan pengetahuan, sikap, dan keterampilan, beserta tingkatannya".

Hasil belajar berwujud kemahiran. Pasca belajar seseorang akan mempunyai keterampilan, pengetahuan, sikap, serta nilai. Munculnya kemahiran tersebut muncul dari (i) rangsangan lingkungan, serta (ii) proses pengetahuan yang dilaksanakan oleh peserta didik, Gagne dalam Dimyati \& Mudjiono (2013: 10).

Burton dalam Rusman dkk (2011: 8) berpendapat bahwa "hasil belajar dapat diukur dengan cara bagaimana proses dilaksanakan, apakah sesuai dengan aturan yang benar. Proses yang betul akan menciptakan sesuatu yang berguna saat dikembalikan ke masyarakat sebagai outcome".
Kulminasi dari proses pembelajaran disebut hasil belajar, Dimyati \& Mudjiono (2013: 20). Hasil belajar terjadi karena penilaian dari pengajar. Hasil belajar berwujud akibat pengajaran dan akibat pengiring. Kedua akibat tersebut bermanfaat bagi pengajar dan pebelajar". Oleh sebab itu, hasil belajar yakni suatu perilaku yang meliputi pengetahuan, sikap, dan keterampilan yang diukur melalui proses belajar.

Sumadi Suryabrata (2010:233) , "Hasil belajar dipengaruhi oleh aspek internal dan eksternal. Faktor dari dalam yakni terdiri dari faktor fisiologis dan faktor psikologi. Faktor dari luar yaitu faktor sosial dan bukan sosial".

a. Faktor fisiologis

Faktor ini meliputi jasmani, dan kondisi fungsifisiologis. Kondisi jasmani yang sehat membantu memudahkan peserta didik menguasai pembelajaran dibanding kondisi jasmani yang tidak sehat.

b. Faktor psikologi

Faktor ini mempunyai kedudukan untuk memotivasi peserta didikdalam memahami pelajaran.

c. Faktor non sosial

Menurut Sumadi Suryabrata (2010:233), "Beberapa faktor nonsosialyang berpengaruh terhadap proses belajar yakni kondisi udara, suhu, iklim, waktu, lokasi, dan media belajar".

d. Faktor sosial

Sumadi Suryabrata (2010:234) menjelaskan bahwa "faktor sosial yakni hubungan manusia, baik itu ada maupun tidak ada".

Dimyati \& Mudjiono (2013:238-247) menjelaskan bahwa faktor internal yang mempengaruhi proses belajar yakni: (1) sikap, (2) motivasi, (3) konsentrasi, (4) pengolahan bahan pembelajaran, (5) penyimpanan hasil, (6) penggalian hasil, (7) skill, (8) percaya diri peserta didik, (9) kecerdasan dan keberhasilan belajar, (10) habit belajar, (11) keinginan peserta didik. Faktor dari luar yang berpengaruh terhadap kegiatan belajar peserta didik yakni: (1) guru, (2) peralatan pembelajaran, (3) kebijakan penilaian, (4) sekolah, dan (5) kurikulum, Dimyati \& Mudjiono (2013: 248253)

Kegiatan mendidik agar mampu mengambil keputusan sehingga berkontribusi untuk lingkungannya disebut pendidikan karakter (Kesuma, 2011: 5).

Mustari (2014: 155) Karakter Nasionalis adalah pola pikir yang menunjukkan kesetiaan 
kepada bangsa sehingga memiliki rasa bangga sebagai warga negara.

Penguatan karakter diperlukan untuk memfilter banyaknya budaya asing yang masuk. Sehingga penguatan karakter nasionalis yang cinta terhadap bangsa dan negara sangat perlu untuk dibangkitkan.

Anak-anak SD, mereka memiliki karakteristik yang unik. Dalam memenuhi kebutuhan peserta didik hendaknya memperhatikan karakteristik perkembangannya.

Tahap perkembangan anak secara umum dikemukakan oleh Piaget dalam Sumantri dan Syaodih (2011: 1. 15) menjelaskan bahwa siswa kelas empat berada pada tahap Operasional Konkret (7-11 Tahun). Anak bisa berpikir dengan logis dan sistematis guna memperoleh solusi permasalahan. Masalah anak bersifat konkret. Anak menyelesaikan masalah yang sifatnya abstrak.

\section{METODE}

Kelas IV SD Inpres Semangga 1 Kabupaten Merauke di semester ganjil pada tahun pelajaran 2019/2020 menjadi tempat pelaksanaan penelitian. Penelitian ini merupakan penelitian tindakan kelas (3 siklus yang terdiri dari masing-masing 3 pertemuan). Setiap siklus terdiri dari perencanaan, pelasaksanaan, observasi dan refleksi.

Subjek penelitian yakni siswa kelas IV SD Inpres Semangga 1 Kabupaten Merauke tahun pelajaran 2019/2020. Penentuan subjek penelitian didasarkan karena hasil belajar IPS dan karakter nasionalis siswa perlu ditingkatkan

Data kuantitatif penelitian ini yakni hasil belajar, dan data kualitatif yakni peningkatan karakter nasionalis siswa kelas IV SD Inpres Semangga setelah menggunakan metode pembelajaran peta konsep.

Sumber data penelitian ini yakni siswa, observer dan dokumentasi. Siswa merupakan sumber data penerapan metode pembelajaran peta konsep. Data yang diperoleh dari observer berwujud penggunaan metode pembelajaran peta konsep dan nilai karakter nasionalis siswa. Observer yang dimaksud adalah guru di SD Inpres Semangga 1 Kabupaten Merauke yang akan melakukan pengamatan. Dokumen yang diperlukan adalah buku rapor dan daftar nilai siswa.

Pengumpulan data memakai teknik tes (lembar evaluasi) dan non tes (lembar observasi). Dalam melakukan PTK untuk memperoleh validitas, peneliti menggunakan teknik triangulasi yaitu upaya untuk mengadakan pengecekan kebenaran data berupa triangulasi sumber dan teknik. Indikator kinerja penelitian ini yaitu ketuntasan belajar klasikal 80\% dengan KKM 70.

\section{HASIL DAN PEMBAHASAN}

\section{1 Deskripsi Pra Tindakan}

Penelitian awal memperoleh permasalahan dengan pembelajaran Tematik khususnya pada IPS. Pada materi keberagaman suku bangsa, siswa masih kesulitan dalam memahami dan menguasai materi. Sebagian besar dari mereka masih membutuhkan waktu lama menguasai materi keberagaman suku bangsa. Pemahaman siswa yang kurang mengenai keberagaman yang ada di Indonesia berimbas pada kurangnya perwujudan karakter nasionalisme pada diri siswa.

Hal tersebut didasarkan pada hasil pre-test yang menunjukkan nilai yang masih rendah. Berdasarkan kegiatan tersebut, peneliti memperoleh gambaran bahwa saat pembelajaran berlangsung, siswa kurang aktif, membosankan, kurang dapat bekerja sama. Berdasarkan hasil tes awal (pre-test) yang dilakukan, diperoleh rata-rata nilai yaitu 41,76 sehingga di bawah KKM 70.

\section{1.1 Sub-sub Judul}

Penelitian dilaksanakan dalam tiga siklus (setiap siklus 3 pertemuan). Pada setiap tindakan, guru menggunakan metode peta konsep. Materi yang menjadi fokus penelitian yakni keragaman susku bangsa di Indonesia. Evaluasi akhir siklus dilakukan pada tindakan ketiga di setiap siklus terdiri dari hasil belajar dan penilain karakter siswa. Pada akhir siklus I nilai rata-ratayakni 72,06 . Ketuntasan belajar siswa mencapai $52,94 \%$ (9 siswa). Sedangkan ketidaktuntasan mencapai 47,06\% (8 siswa). Pada akhir siklus I disimpulkan bahwa hasil belajar belum mencapai indikator kinerja yang ditentukan yaitu $80 \%$. Beberapa hal yang menjadi kendala diantaranya belum terjadi interaksi aktif siswa. Pelaksanaan diskusi kelompok belum maksimal. Hasil observasi karakter nasionalis siswa pada akhir siklus I menunjukkan bahwa 17,65 \% karakter nasionalis siswa berkategori sudah membudaya dan $82,35 \%$ karakter nasionalis siswa berkategori mulai berkembang.

Beberapa kendala yang ditemui pada pelaksanaan siklus I diperbaiki pada siklus II. Siklus II terdiri dari tiga tindakan dengan evaluasi dilakukan pada pertemuan ketiga. Hasil belajar siswa pada 
evaluasi akhir siklus II menunjukkan nilai rata-rata 76,47. Ketuntasan belajar siswa mencapai $64,71 \%$ atau sebanyak 11 siswa. Sedangkan ketidaktuntasan mencapai $35,29 \%$ (6 siswa) sehingga akan dilakukan tindakan pada siklus III karena ketuntasan belum mencapai 80\%. Beberapa kendala masih dihadapi pada siklus II diantaranya pada saat presentasi materi, siswa yang tidak presentasi tidak memperhatikan presentasi teman di depan sehingga ketika diberi pertanyaan tentang materi yang dipresentasikan oleh temannya, siswa masih kebingungan. Siswa masih kebingungan saat menyebutkan budaya di sekitar lingkungan siswa. Hanya sebagian kecil siswa yang bisa menjelaskan budaya di lingkungan sekitar siswa. Sementara itu, karakter nasionalis siswa pada akhir siklus II menunjukkan bahwa 29,41\% karakter nasionalis siswa berkategori mulai berkembang dan 70,59\% karakter nasionalis siswa berkategori sudah membudaya.

Siklus III dilakukan karena hasil belajar belum mencapai target $80 \%$ dikarenakan beberapa kendala yang masih ditemui. Permasalahan kurang fokus siswa dan minimnya interaksi siswa dalam kegiatan pembelajaran kemudian diperbaiki pada pelaksanaan tindakan satu, dua dan tiga di siklus III ini. Penggunaan metode peta konsep diimbangi dengan pendekatan saintifik masih dilakukan pada siklus III dengan beberapa perbaikan dan improvisasi. Siklus III menunjukkan nilai rata-rata 80,59 . Ketuntasan belajar siswa mencapai $82,35 \%$ atau sebanyak 14 siswa. Sedangkan ketidaktuntasan mencapai 17,65\% (3 siswa). Siklus III sudah mencapai indikator kinerja yang ditentukan yaitu $80 \%$, sehingga tindakan dihentikan.

Sedangkan penilaian karakter nasionalis siswa berdaasrkan observasi yang dilakukan menunjukkan bahwa enam belas orang siswa atau $94,12 \%$ sudah memiliki karakter nasionalis pada kategori sudah membudaya dan satu orang siswa atau $5,88 \%$ pada kategori mulai berkembang berdasarkan indikator yang telah ditetapkan, sehingga tindakan bisa dihentikan pada siklus ketiga. Hasil belajar dan penilaian karakter nasionalis siswa pada setiap siklus disajikan pada gambar 1 dan 2.

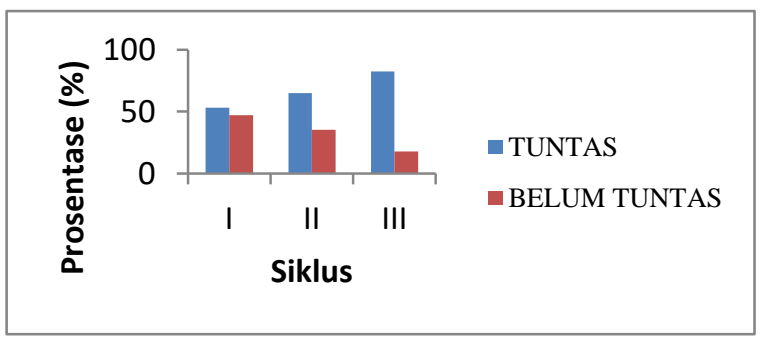

Gambar 1. Ketuntasan belajar tiap siklus

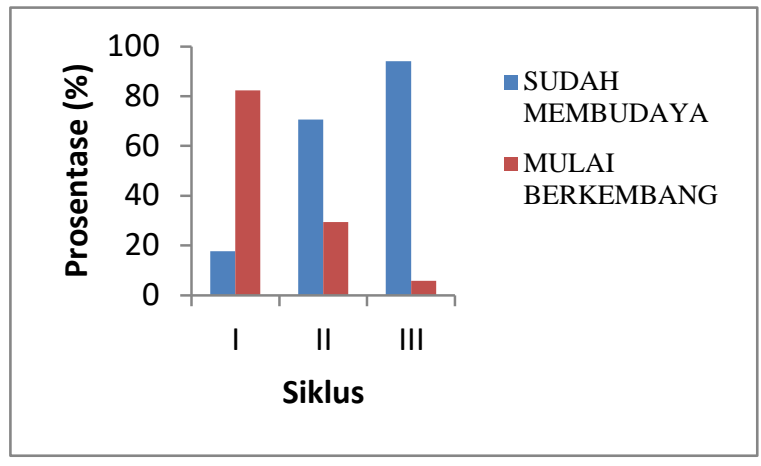

Gambar 2. Penilaian karakter nasionalis siswa tiap siklus.

\section{KESIMPULAN}

Penggunaan metode pembelajaran peta konsep dapat meningkatkan Hasil Belajar IPS Tema Indahnya Keragaman di Negeriku dan Karakter Nasionalis Siswa Kelas IV SD Inpres Semangga 1 Merauke. Hal tersebut didasarkan pada hasil penelitian dan pembahasan.

Hasil belajar IPS $\geq K K M$ yang ditentukan yaitu 70. Hasil pretes siswa memperoleh rata-rata 41,76 meningkat pada siklus I menjadi 72,06, siklus II 76,47 dan siklus III 80,59. Karakter nasionalis siswa pada siklus I menunjukkan bahwa $82,35 \%$ karakter nasionalis siswa berkategori mulai berkembang dan 17,65 \% karakter nasionalis siswa berkategori sudah membudaya. Hasil observasi karakter nasionalis siswa pada akhir siklus IImeningkat yakni $29,41 \%$ karakter nasionalis siswa berkategori mulai berkembang dan $70,59 \%$ karakter nasionalis siswa berkategori sudah membudaya. Siklus III menunjukkan 94,12\%siswa sudah memiliki karakter nasionalis pada kategori sudah membudaya dan $5,88 \%$ siswa pada kategori mulai berkembang.

\section{DAFTAR PUSTAKA}

Dahar, R. W. (2011). Teori-Teori Belajar dan Pembelajaran. Jakarta: Erlangga.

Dimyati dan Mudjiono. 2013. Belajar dan Pembelajaran. Rineka Cipta: Jakarta.

Fahzurrohman, M. (2015). Model-Model Pembelajaran Inovatif. Jogjakarta: Ar-Ruzz Media.

Junaedi, dkk. (2008). Strategi Pembelajaran. Surabaya: LAPIS-PGMI. 
Kesuma, Dharma MPd, dkk. 2011. Pendidikan Karakter Kajian Teori dan Praktik di Sekolah. Bandung: PT. Remaja Rosdakarya.

Mustari, Mohamad. 2014. Nilai karakter Refleksi untuk Pendidikan . Jakarta: Raja Grafindo Persada.

Rusman, dkk. (2011). Pembelajaran Berbasis Teknologi Informasi dan Komunikasi Mengembangkan Profesionalitas Guru. Jakarta: Rajawali Press.

Sumantri, M. \&Syaodih, N. (2011). Perkembangan Peserta Didik. Jakarta:Universitas Terbuka.

Suryabrata, Sumadi. (2010). Psikologi Pendidikan. Rajawali Press: Jakarta

Warsono dan Hariyanto. (2012). Pembelajaran Aktif. Bandung: Remaja Rosdakarya.

Yusron, M. (2013). Creative Learning. Bandung: Nusa Media. Dahar, R. W. (2011). TeoriTeori Belajar dan Pembelajaran. Jakarta: Erlangga 